\title{
CHANGES IN FAMILY STRUCTURE IN LATVIA: TRENDS AND CHALLENGES
}

Jolanta Millere ${ }^{1}$, Dr.sc. soc.

\section{${ }^{1}$ Latvia University of Life Sciences and Technologies}

Abstract. Nowadays, we can observe various changes in family structure, which lead to the need to change the traditional understanding of the family. These changes can be explained by the prevalence of the globalization process in society, which have affected almost all spheres of life, including the family institute. Within the article, based on the analysis of statistical data and literature, the current trends of changes in family structure and related challenges will be described. When analysing changes in family structure, it is necessary to focus on both - structural and qualitative changes, which were reflected in the composition of families, trends in marriage registration, as well as in relationships between family members. The most characteristic changes show increase of such families with children where cohabiting partners are living together without registering the marriage as well as decreasing amount of nuclear families and increasing amount of single-parent families. This trend leads to other qualitative changes in family structure - several challenges of social policy because single-parent families often face different problems related to effective functioning of the family. For example, single-parent families with children are more often at risk of poverty than nuclear families, as well as face various types of problems in meeting the needs of the family. Social policy planners, when designing support for families with children, should take into account the specifics of single-parent families and provide them support according to the needs of these families, without waiting when families will fall into the social risk category.

Key words: family, nuclear family, single-parent family, family structure, changes.

JEL code: $\mathrm{J} 12$

\section{Introduction}

Globalization has brought many different changes in all areas of life, including changes in family life. The family is the most important social institute, which is responsible for the reproduction of society and the socialization of the new generation in accordance with the needs of society. In order for a family to be able to perform its functions effectively, it must be stable and able to meet the needs of the family. Traditionally, it is the nuclear family, which includes father, mother and children, that is considered stable, but in today's changing world, the form of the nuclear family has long since ceased to be the most popular. This is also confirmed by statistics. In Latvia, at the beginning of 2020, the number of families with minor children has significantly decreased, but the number of single-parent families with children has increased. In 2011, 232.7 thousand families with minor children lived in Latvia, of which $38.9 \%$ were single-parent families, but at the beginning of 2020 - only 220 thousand such families, of which $54.7 \%$ had single parent with one or more minor children. The increase in single-parent families is related to several factors - Latvia has the highest divorce rates in the European Union (3.1 divorces per 1000 inhabitants per year in 2019, where almost half of the cases involved minor children (Latvijas statistikas gadagramata..., 2021), high extramarital births (about $40 \%$ of children are born out of wedlock each year), as well as high emigration (more than a quarter of the emigrants are men aged $25-44$, of whom $1 / 3$ were married) (Pieaug neregistreta kopdzive..., 2013).

The aim of the article is to reflect the structural and qualitative changes of families with minor children, the related trends and challenges. The used research methods are the analysis of scientific literature and statistical data. In Latvia, some important statistical data on the structure of families are available mainly from the results obtained during the Census in 2011, so this is a reason for included statistical data in the article by 2011 .

The reflected trends in family structure suggest that traditional, implemented over time, family policy activities in the field of family support need to be reviewed and changed in line with changes in family 
structure in society, because single-parent families with minor children face the highest material deprivation compared to other types of families and have the highest poverty index (Nabadzibas riska indekss..., 2020).

\section{Characteristics of changes in family structure}

The family is the primary and most sustainable social institution, which is important for both the individual and society as a whole, as a predetermined social unit including all members of society. The concept of "family" is widely used in everyday life, most people feel the meaning of "family", an intuitive understanding of the concept is sufficient for everyday communication and activities. Within sociology, "family", like the social reality it embodies, is a complex and controversial concept, the definition of which has become a topical issue in modern sociology, raising the question: who and what is called family, and more and more relatives are being replaced with the support of close relationships of people unrelated by blood. In modern society, the family is experiencing significant social changes linked to globalization, industrialization, urbanization and secularisation.

In today's society, it is difficult to define the concept of family, each approach looks at the processes that define the boundaries of relationships and families in relation to what we include in the family and what it should be.

Traditionally, the family is defined as a group of people with whom we can be biologically connected and with whom we feel a kinship (P. McNeill..., 2003: 26).

Family institute provides a definition of the family, emphasizing one of the three important aspects of the explanation of the family:

- family structure in both qualitative and quantitative contexts;

- functional interaction of families with society;

- internal interactivity of family members (mutual relations of family members, communication, interaction) (Collins, R. ..., 1995).

The article will pay more attention to the presentation of family structure issues.

The division of family structure envisages typology of families according to various features; for example, according to the composition of the family, families are divided into nuclear (mother, father and children) families, one parent (or single-parent) (one parent and child or children) families, as well as extended (in addition to parents and children there are other family members, such as grandparents) families (Collins R.,..., 1995). Although nuclear families have long been losing popularity in Europe and have been replaced by single-parent families, for example in the United Kingdom in $197192 \%$ of families were nuclear families, compared to $78 \%$ in 1993 and $74 \%$ in 2000, but in 2001 only $23 \%$ of families were nuclear because of the rapid increase in single-parent families (McNeill P. ..., 2003:27). In Latvia, also nuclear-type families have lost their popularity over time (Table 1). According to statistical data, in 2011 in Latvia, $61 \%$ of all families with minor children were nuclear families, while in the 2020 only $45 \%$.

For a variety of reasons, there are a large number of single families, and this number continues to grow. The increase in single families can be explained not only by the high number of divorces, but also by the difficulties in creating a healthy family life, which is related to the qualitative changes of the family. Increasingly, cohabiting partners, choosing to live together without marriage, are aware of the possibility of raising children alone, as evidenced by statistics. Comparing single-parent families in 2011 by composition with single-parent families in 2020, it can be concluded that single-parent families consist mainly of mothers with children - in $201186 \%$, but in 2020 - $85 \%$ of all single-parent families. According to statistical data, in 2020 there is a slight increase of single parent - father's - families by one percent 
(Table 1). From the statistics, it can be concluded that the main responsibility for raising children is still taken by mothers.

Table 1

Nuclear and single-parent families in 2011 and 2020

\begin{tabular}{|c|c|c|c|c|c|}
\hline \multirow[b]{2}{*}{ Year } & \multirow{2}{*}{$\begin{array}{l}\text { Families } \\
\text { with } \\
\text { children, } \\
\text { number }\end{array}$} & \multirow{2}{*}{$\begin{array}{c}\text { Nuclear } \\
\text { families, } \\
\text { number } \\
\text { and } \%\end{array}$} & \multirow{2}{*}{$\begin{array}{c}\text { Single-parent } \\
\text { families with } \\
\text { children, } \\
\text { number and } \\
\%\end{array}$} & \multicolumn{2}{|c|}{$\begin{array}{c}\text { From all single-parent } \\
\text { families: }\end{array}$} \\
\hline & & & & $\begin{array}{c}\text { Single mother } \\
\text { families, } \\
\text { number } \\
\text { and } \%\end{array}$ & $\begin{array}{l}\text { Single father } \\
\text { families, } \\
\text { number } \\
\text { and } \%\end{array}$ \\
\hline 2011 & 232728 & $143194(61 \%)$ & $90534(39 \%)$ & $78157(86 \%)$ & $12377(14 \%)$ \\
\hline 2020 & 220000 & $99725(45 \%)$ & $120272(55 \%)$ & $102501(85 \%)$ & $17771(15 \%)$ \\
\hline
\end{tabular}

Source: author's calculations based on data of Central Statistical Bureau of Republic of Latvia, Type of family nucleus in regions, cities under state jurisdiction and counties at the beginning of the year 2011 and 2020

According to the information provided in Table 1, not only the family structure according to the composition of their members has changed over time, but also the total number of families with children in 2020 there were $5.5 \%$ fewer families with children than in 2011 . Changes in the family structure also reflect the rapid growth of single-parent families - in 2011, single-parent families in Latvia accounted for $39 \%$ of the total number of families, but in 2020 - already $55 \%$ of the total number of families. The reflected tendencies are related to the high number of divorces in Latvia, as well as to the tendency not to register marriages. There is no data available about divorces in 2020 . According to statistics, the number of registered marriages has fallen, especially in the last four years. In 2019, 12861 marriages were concluded in Latvia, whereas 5971 marriages were divorced. The number of marriages per 1000 inhabitants comprised 6.7 and the number of divorces 3.1 (Table 2). In 2020, 10723 marriages were registered in Latvia, which is 2138 marriages less than in 2019.

Table 2

Number of marriages and divorces in Latvia

\begin{tabular}{|l|c|c|c|c|}
\hline \multicolumn{1}{|c|}{ Indicator } & $\mathbf{2 0 1 7}$ & $\mathbf{2 0 1 8}$ & $\mathbf{2 0 1 9}$ & $\mathbf{2 0 2 0}$ \\
\hline Number of marriages & 13150 & 13058 & 12861 & 10723 \\
\hline Number of divorces & 5943 & 5967 & 5971 & Not available \\
\hline
\end{tabular}

Source: author's calculations based on data of Central Statistical Bureau of Republic of Latvia, Divorces and marriages in regions, cities and municipalities by Territorial unit, Indicator and Time period, 2017-2020

There are several reasons for the declining trend in marriage registration, and the author mentions the change in values in society as the main reason - members of society no longer attach as much importance to marriage as before, so cohabiting partners no longer feel pressure from society to register their cohabitation. Of course, economic reasons and experience gained in the socialization process can also be mentioned as a reason for not registering a marriage, but they are not decisive in the author's opinion (marriage registration is not so expensive as to make people to avoid marriage registration). The decline in the number of marriages leads to a trend towards fewer children in the family and one of the reasons can be unstable family structure. Today's society is characterized by one child in the family. There are various reasons for this trend: 
- the family is limited by economic conditions;

- marital instability;

- any illness of the spouse;

- changes of value system (Collins, R. ..., 1995).

As statistical data shows in 2011 there were $17.4 \%$ families with one child, $8.1 \%$ families with two children, but only $2.6 \%$ families with three and more children from all families in total (with and without children) (Table 3). The statistical data shows, that at the beginning of 2020 there were $14.5 \%$ families with one child, $9.1 \%$ families with two children and only $3.6 \%$ families with three and more children from all families in total (with and without children) (Table 3). According to statistics, from 2011 to the beginning of 2020, the number of families with children has decreased, while the trend that reflects the superiority of one-child families over families with two, three or more children, remains unchanged. It can be concluded from the above that taking into account the numerous activities carried out by the state with the aim to improve the demographic situation of the state, however, the trends show the slow results of these measures.

On the one hand this tendency reflects the situation that adult family members don't feel secure and stable in society to grow up more than one child, but on the other hand families have high standards for living that is difficult to realize with more than one child as well as the high percent of non-registered relationships between cohabiting partners create the uncertainty in relations.

However, the fact that cohabiting partners do not register their cohabitation does not mean that they do not have a family; for example, in $2011,15.3 \%$ of cohabiting partners had not registered their cohabitation, but were raising minor children.

Table 3

Households (families) by number of children (\%) 2011 and 2020

\begin{tabular}{|c|c|c|c|c|c|}
\hline Indicator & $\begin{array}{c}\text { Families } \\
\text { without } \\
\text { children }\end{array}$ & $\begin{array}{c}\text { Families } \\
\text { with one } \\
\text { child }\end{array}$ & $\begin{array}{c}\text { Families } \\
\text { with two } \\
\text { children }\end{array}$ & $\begin{array}{c}\text { Families with } \\
\text { three or more } \\
\text { children }\end{array}$ & $\begin{array}{c}\text { In total all } \\
\text { families in } \\
\text { Latvia }\end{array}$ \\
\hline $\begin{array}{l}\text { Families with minor } \\
\text { children in 2011, \% }\end{array}$ & 71.9 & 17.4 & 8.1 & 2.6 & 100 \\
\hline $\begin{array}{l}\text { Families with minor } \\
\text { children in 2020, \% }\end{array}$ & 72.8 & 14.5 & 9.1 & 3.6 & 100 \\
\hline
\end{tabular}

Source: author's calculations based on data of Central Statistical Bureau of Republic of Latvia. Households by number of children (per cent), 2005 - 2020

From the above it can be concluded that the concept of "family" has a social meaning, which can change along with the social changes of the society. The definition of the family has also changed as a result of social change, as the concept of the family needed to be extended to include family members who are not related by kinship or biological ties: the family is made up of people who think of themselves as part of the family, whether or not they are linked by blood or marriage, and who regularly care for each other (Mannan H..., 2003)

As the analysis of the literature shows, in connection with changes in family structure, it is possible to distinguish two types of changes that families have "experienced" - structural changes and qualitative changes. 
Structural change in families is associated with undergone massive change; more family forms are now acceptable. Much of the evidence for such change comes from government statistics on births, marriage and divorce. When describing the structural changes in families, it is important to mention the changes related to the decrease in the birth rate, the decrease in the number of marriages and the increase in divorces, as well as the desire of individuals to live alone (separately from their relatives), the desire to live together when the children have already left parents' home or have not yet been born, as well as with the spread of the mixed family type, which envisages living with children from another marriage / cohabitation (McNeill P. ..., 2003:32). Structural change in families has marked another negative trend prevalence of unstable family structure - due to the increase in the number of divorces, there is a high probability that a new cohabiting partner may enter the family in an unforeseen period of time - for the child stepfather or stepmother as well as other family members (stepbrother or stepsister). This trend can lead to negative qualitative changes in the family, such as unfavourable treatment of children by stepfathers or stepmothers, even the possibility of various types of violence. According to the 2019 report of the State Inspectorate for Protection of Children's Rights of Republic of Latvia, during 2019 hotline calls were received from children suffering from abuses by stepfathers, stepmothers, as well as stepbrothers or stepsisters: "... stepmother often insults a girl, cursing. She has tried to talk with her mother and also with father, but nothing has changed."," ... Stepbrother regularly beats and tweaks, but the mother does not react and does not stand for the daughter...", The girl is confused about the fact that she can't decide where to live whether with her mother or father" (Valsts bernu tiesibu..., 2019). The unstable family structure often leads to different psychological problems between family members as well as to different kinds of violation that can decrease the family functionating. It can be concluded from the above that changes in family structure are related to the "entry" of various new problems into family life, to which social policy planners and implementers should respond by providing support activities with a aim to improve family functionality. The sphere of social services for families should be developed in accordance with the qualitative changes in the family structure related to changes in the relationship between people in the family.

The evidence here is much less clear cut. When describing the qualitative changes in the family structure, it is necessary to mention equal positions between husband and wife, the relationship between children and parents is no longer so close, because parents have to earn money and are often forced to work in several jobs, leaving no time to raise children. Sociologists (Peter Saunder) emphasize that this has contributed to the spread of social problems in the field of juvenile delinquency, especially in the context of single-parent families (McNeill P. ..., 2003:32). The negative impact of these changes is also observed in Latvia, as evidenced by the analysis of statistical data on juvenile convictions. Children in single-parent families are at high risk of poverty, social exclusion and mental health disorders, and criminal offenses are more often committed by minors growing up in a single-parent family: in 2018, 304 children were detained and placed in the State Police Department, of which 177 children were from single-parent families (Nepilngadigo noziedziba ...2019). Parents who raise children alone, on the other hand, experience emotional stress and often have difficulty fulfilling their role. Another trend is that more and more members of society support the coexistence of homosexuals and are more tolerant of extramarital and premarital sexual relations. The trends shown are not only a change in the values of society, but also an understanding of the concept of family and marriage: members of society increasingly no longer see family and marriage as an intimate union. From the information provided, it can be concluded that changes affecting families affect the daily lives of families, as well as society as a whole, so the negative consequences of these changes should be analysed and the causes of these consequences should be addressed, involving policy makers and implementers of various sectors. One of the ways to support families in difficulty is to set up a 
support system that meets the needs of modern families, providing not only financial support for families, but also various types of rehabilitation services. As statistics show, single-parent families, more than other types of families by composition, face financial difficulties and the risk of poverty.

\section{Trends and challenges of structural and qualitative changes in families in Latvia}

As mentioned in the article above, the family is in a constant state of change. Changes also permeate everyday family life, such as changes in the roles of women and men in the emphasis on gender equality in society or in the status of children, with children increasingly enjoying a dignified status linked to the development of children's rights (McNeill..., 2003). In this context, it can be concluded that all types of families are experiencing various structural $P$. changes due to wider structural and qualitative changes. For example, single-parent families face financial difficulties more than nuclear with one or more children (Table 4).

According to statistics, single-parent families have a higher index of material deprivation. Although it has decreased over time from $64.5 \%$ in 2011 to $29.1 \%$ in 2019 that could be explained by economic situation in the country, but it has remained consistently higher than for other family types throughout the period covered by the analysis. Material deprivation index shows the tendency that single-parent families with children have the similar financial circumstance with nuclear families with 3 and more children. In turn, the lowest index of material deprivation is for a nuclear family with one child, which confirms the trend of modern change discussed above for women to give birth less in order to promote material security.

Material deprivation is closely linked to the at-risk-of-poverty index. Analysing the type of family most at risk of poverty, it can be concluded that single-parent families are most at risk of poverty: although compared to 2011 (41.5\% of all families at risk of poverty are single-parent families) the risk of poverty has decreased to $30.6 \%$ in 2019 , however, it maintains a high trend compared to other types of families (Table 5).

Table 4

Material deprivation index of the families with children, (\%)

\begin{tabular}{|c|c|c|c|c|}
\hline Year & $\begin{array}{c}\text { Single-parent } \\
\text { families with } \\
\text { child/children }\end{array}$ & $\begin{array}{c}\text { Nuclear } \\
\text { family } \\
\text { with one } \\
\text { child }\end{array}$ & $\begin{array}{c}\text { Nuclear } \\
\text { family with } \\
\text { two children }\end{array}$ & $\begin{array}{c}\text { Nuclear family } \\
\text { with 3 and } \\
\text { more children }\end{array}$ \\
\hline 2011 & 64.5 & 38.4 & 37.7 & 64.4 \\
\hline 2016 & 40.5 & 18.8 & 16.3 & 32.8 \\
\hline 2017 & 33.1 & 11.8 & 12.5 & 23.9 \\
\hline 2018 & 31.9 & 9.4 & 11.9 & 27.5 \\
\hline 2019 & 29.1 & 7.2 & 8.7 & 18.2 \\
\hline
\end{tabular}

Source: author's calculations based on data of Central Statistical Bureau of Republic of Latvia, Material deprivation rate among persons (\%) by Indicator and Time period

Comparing the poverty risk trends of nuclear and single-parent families, it can be concluded that nuclear families with one child are least exposed to the risk of poverty, which is also confirmed by data on material security. 
At risk of poverty rate by family type (\%)

\begin{tabular}{|l|c|c|c|c|c|}
\hline \multicolumn{1}{|c|}{ Indicator } & $\mathbf{2 0 1 1}$ & $\mathbf{2 0 1 6}$ & $\mathbf{2 0 1 7}$ & $\mathbf{2 0 1 8}$ & $\mathbf{2 0 1 9}$ \\
\hline All families with children & 20.7 & 16.3 & 16.5 & 14.3 & 15.6 \\
\hline Single-parent family with children & 41.5 & 34.3 & 32.6 & 26.2 & 30.6 \\
\hline Nuclear family with a child & 16.8 & 13.4 & 12.1 & 16.2 & 12.2 \\
\hline Nuclear family with two children & 18.7 & 14.4 & 10.2 & 11.1 & 12.8 \\
\hline
\end{tabular}

Source: author's calculations based on data of Central Statistical Bureau of Republic of Latvia, At-risk-of-poverty rate by household type (\%) by Household's type and Time period 2011 - 2019

Due to the high risk of poverty, single-parent families are also exposed to other risks to family functions, such as constant emotional stress due to material deprivation, as well as excessive participation in paid employment in order to earn as much as possible. This, in turn, results in the neglect of children, as well as a careless attitude towards meeting their needs. As a result, single-parent families are in the most vulnerable situation, which requires the immediate involvement of the state and local governments through the implementation of various measures. However, despite the different forms of relationships and the broadening of the definition of family, among policy planners and implementers, the traditional concept of the family remains strong (Schadler C., 2016). This is also evidenced by the analysis of regulatory enactments in the field of social policy, as single-parent families are not identified as a priority group of support, considering that all families should be supported equally, paying attention to the material situation of families without assessing the capacity of families to function effectively.

\section{Conclusions and recommendations}

1) When analysing aspects related to the family life, it is no longer possible to use the traditional definition of families, which describes the family as a group of relative members because family life has become more diverse in various respects both in terms of family composition and in terms of the family affiliation of family members.

2) When analysing changes in family structure, it is necessary to focus on both structural and qualitative changes in families, which are reflected to the composition of families, trends in marriage registration, in the role implementation of family members as well as in the relationships between the family members.

3) As the trends reflect, not only nuclear but also the total number of families with children is decreasing in Latvia. Single-parent family type is becoming more and more popular not only in Latvia, but also in other European countries.

4) According to the analysis of statistical data, the number of partners living in unregistered cohabitation with children is rapidly increasing. That leads to unstable family structure. An unstable family structure is associated with experiences that involve living together with new family members, who do not always develop a favourable and family-friendly relationships.

5) Single-parent families with children are more often at risk of poverty than nuclear families, as well as face various types of problems in meeting the needs of the family.

6) Social policy planners and implementers, when designing and implementing support for families with children, should take into account the specifics of single-parent families and provide them with support according to the needs of these families, without waiting when families will fall into the social risk category. 
7) Gaining experience in working with statistical data available in Latvia, it can be concluded that for analysing information related to family structure, statistical data on families are incomplete, for example, a large part of the data presented for 2011 cannot be found for another period after 2011 for the year. Also, the information on the structure of families by family composition is also very fragmentary. Consequently, it can be concluded that in order to be able to qualitatively analyse the processes related to family welfare and, based on them, to improve social policy activities, it is necessary to pay more attention to the development of access to the statistical data in Latvia.

\section{Bibliography}

1. Collins R., Coltrane S. (1995). Sociology of Marriage and the Family: Gender, Love, and Property. Nelson-Hall, $581 \mathrm{pp}$.

2. Gimenu skaits ar nepilngadigiem berniem pec gimenes kodola veida un bernu skaita pa statistiskajiem regioniem, republikas pilsetam un novadiem 2011.gada 1.marta. Centrala statistikas parvalde. Riga, 2012. (Distribution of households by number of children (per cent) 2005 - 2020. Central Statistical Bureau of Latvia. Riga, 2012.) Retrieved: https://data.stat.gov.Iv/pxweb/en/OSP_PUB/START_POP__MV_MVE/MVE050/ Access: .20.03.2021.

3. Gimenes kodola veids regionos, republikas pilsetas un novados 2020. gada sakuma. Centralas statistikas parvalde. Riga, 2020 (Type of family nucleus in regions, cities under state jurisdiction and counties at the beginning of the year 2020. Central Statistical Bureau of Latvia. Riga, 2020 Retrieved:

https://stat.gov.Iv/lv/statistikas-temas/iedzivotaji/privato-majsaimniecibu-skaits/tabulas/mvg020-gimeneskodola-veids? themeCode $=$ MV Access: 22.03.2021.

4. Iedzivotaju materialas nenodrosinatibas indekss (\%) 2011 - 2019. Centralas statistikas parvalde. Riga, 2020. (Material deprivation rate among persons (\%) by Indicator and Time period. Central Statistical Bureau of Latvia. Riga,2020) Retrieved: https://data.stat.gov.Iv/pxweb/en/OSP_PUB/START_POP_NN_NNN/NNN130/ Access: 18.03.2021.

5. Latvijas statistikas gadagramata 2020. Centrala statistikas parvalde. Riga, 2021 (Statistical Yearbook of Latvia 2020. Riga, 2021. Retrieved:

https://admin.stat.gov.Iv/system/files/publication/202102/Nr_01_Latvijas_statistikas_gadagramata_2020_Stati stical\%20Yearbook\%20of\%20Latvia_\%2820_00\%29_LV_EN.pdf Access: 18.03.2021.

6. Mannan H., Marquis J., Park J., Poston D., Turnbull A., Wang M. (2003). Family Quality of Life: A Qualitative Inquiry. Retrieved:

https://www.researchgate.net/publication/10576449_Family_Quality_of_Life_A_Qualitative_Inquiry Access: 19.03.2021.

7. McNeill P., Blundell J., Griffithes J. (2003). Sociology as The Complete Companion. Nelson Thores Ltd.159pp.

8. Nabadzibas riska indekss pec gimenes tipa (\%) (At risk of poverty rate by household type (\%) by Household's type and Time period.) Retrieved: https://data.stat.gov.Iv/pxweb/en/OSP_PUB/START_POP_NN_NNR/NNR040/ Access: 18.03.2021.

9. Nepilngadigo noziedziba Latvija 2018.gada. (2019). (Juvenile delinquency in Latvia in 2018) Retrieved: https://lvportals.Iv/skaidrojumi/305072-nepilngadigo-noziedziba-latvija-2018-gada-2019 Access: 10.03.2021.

10. Noslegto un skirto laulibu skaits regionos, republikas pilsetas un novados $1990-2019$. Centrala statistikas parvalde. Riga, 2020. (Number of marriages and divorces in regions, cities and counties of the Republic 1990 2019. Central Statistical Bureau of Latvia.) Retrieved: https://data.stat.gov.Iv/pxweb/Iv/OSP_PUB/START_POP_IL_ILN/ILNO20 Access: 20.03.2021.

11. Pieaug neregistreta kopdzive dzivojosu paru gimenu ipatsvars. 2013. (Share of couple living in consensual union is growing. Central Statistical Bureau of Latvia.) Retrieved: https://stat.gov.Iv/en/statisticsthemes/population/private-households/press-releases/3639-share-couples-living-consensual. Access: 15.03.2021.

12. Schadler C. (2016). How to Define Situated and Ever-Transforming Family Configurations? A New Materialist Approach. Journal of Family Theory \& Review. Published by Wiley Periodicals, Inc. On behalf of National Council on Families Relations. Open access Journal. Retrieved:

https://onlinelibrary.wiley.com/doi/epdf/10.1111/jftr.12167 Access: 12.03.2021.

13. Valsts bernu tiesibu aizsardzibas inspekcijas 2019. gada publiskais parskats. Labklajibas ministrija.Riga, 2020. (Ministry of Welfare. Public Report of the State Inspectorate for the Protection of the Rights of the Child for 2019.) Retrieved: https://www.bti.gov.Iv/lv/parskats-valsts-bernu-tiesibu-aizsardzibas-inspekcijas-2019-gadapubliskais-parskats-0 Access: 25.03.2021. 